\title{
Philosophy in Poland: Varieties of Anti-Irrationalism. A Commitment to Reason without the Worship of Reason
}

\author{
Konrad Werner ${ }^{1}$ (D)
}

Received: 27 April 2018 /Revised: 25 March 2019 / Accepted: 26 March 2019 /

Published online: 23 April 2019

(C) The Author(s) 2019

\begin{abstract}
I shall elaborate more on the idea of anti-irrationalism proposed by the Polish analytic philosopher Kazimierz Ajdukiewicz, a prominent member of the Lvov-Warsaw School of philosophy and logic. In my reading, anti-irrationalism stands in opposition not only to overt irrationalism, which is made clear by the term itself, but also to all forms of rationalism that tip toward something like worship of reason. Having characterized anti-irrationalism as it originally appeared in Ajdukiewicz's works, I shall propose a certain reformulation (and generalization) of it, so as to capture a broader philosophical legacy in Poland, primarily, yet not exclusively the Lvov-Warsaw School.
\end{abstract}

Keywords Anti-irrationalism · Rationalism · Ajdukiewicz · Lvov-Warsaw School · Polish philosophy $\cdot$ Poland $\cdot$ World-perspective

There is an explanation as to why Alfred Tarski had the courage to tackle the problem of truth in the early 1930s (see Tarski 1983), a problem saddled with deep-seated philosophical controversies, while the intellectual atmosphere among his colleagues in the Vienna Circle drove many of them away from any semantic considerations (see Woleński and Simons 1989). Aware of the controversies, yet undeterred, Tarski wrote:

I hope nothing which is said here will be interpreted as a claim that the semantic conception of truth is the "right" or indeed the "only possible" one. I do not have the slightest intention to contribute in any way to those endless, often violent discussions on the subject: "What is the right conception of truth?" I must confess I do not understand what is at stake in such disputes; for the problem itself is so vague that no

Konrad Werner

konrad.t.werner@gmail.com

1 Institute of Philosophy, University of Warsaw, Krakowskie Przedmieście 3, 00-927 Warszawa, Poland 
definite solution is possible. In fact, it seems to me that the sense in which the phrase "the right conception" is used has never been made clear. In most cases one gets the impression that the phrase is used in an almost mystical sense based upon the belief that every word has only one "real" meaning (...), and that all the competing conceptions really attempt to catch hold of this one meaning (...)

It seems to me obvious that the only rational approach to such problems would be the following: We should reconcile ourselves with the fact that we are confronted, not with one concept, but with several different concepts which are denoted by one word; we should try to make these concepts as clear as possible (by means of definition, or of an axiomatic procedure, or in some other way); to avoid further confusions, we should agree to use different terms for different concepts; and then we may proceed to a quiet and systematic study (...) (Tarski 1944: 355)

So, on the one hand, Tarski dismissed the philosophical controversies piling up over hundreds and thousands of years; on the other hand, however, he apparently wasn't so embarrassed by these controversies and they did not scare him away from tackling the notion of truth once he had recognized its significance in the domain of formal languages.

Here is part of the explanation: Tarski belonged to a logico-philosophical school that imposed methodological conditions on philosophy and thinking that were just as demanding as those informing the Vienna Circle, yet without limiting the scope of the philosophical endeavor (more on the relationship between these two schools see Woleński 1989a). These conditions, briefly put, were rigorous when it came to method and more lenient with respect to subject matter. I am talking about the Lvov-Warsaw School of philosophy and logic (hereafter LWS) which, according to some (e.g., Wansing 2002; Lapointe et al. 2009; Beziau 2018), was one of the most important philosophical breeding grounds in the twentieth century (see Skolimowski 1967 and Woleński 1989b, 2017; also Jadacki 2009; Murawski 2014; Brożek et al. 2017; Garrido and Wybraniec-Skardowska 2018). The LWS is most famous for its developments in logic, yet its major tenet (which laid the groundwork for the abovementioned achievements in logic, ontology, history of ideas, aesthetics, and many other disciplines), was metaphilosophical in nature. It was aptly captured by the Polish analytic philosopher Kazimierz Ajdukiewicz, author of the neologism "anti-irrationalism," in the 1930s, a prominent member of LWS (for a broader overview of the heritage of Ajdukiewicz see Sinisi and Woleński 1995 in English; and Jedynak 2003 in Polish).

I shall elaborate more on the idea of anti-irrationalism, understood as a philosophical program rather than a distinct conception. Having characterized anti-irrationalism, I will provide a broader picture of LWS and the context in which it emerged. Having done that, I will come back to Tarski's attitude which I will treat not so much as a philosophical problem on its own, but as a possible item of interest for readers interested in the history of analytic philosophy and logic, who are now making their decision as to whether they want to carry on reading this paper. Tarski's attitude toward philosophical issues is here invoked as an exemplification of a way of thinking that I would like to unpack and advocate.

In my reading the philosophical program of anti-irrationalism stands in opposition not only to overt irrationalism, which is made clear by the term itself, but also to all forms of rationalism that tip toward something like worship of reason (or Reason), be it reason allegedly inherent in being as such, in history, in evolving matter, in social progress (or 
regress), in developing science, etc. The point is that worshiping reason (Reason) paradoxically breaches the boundaries of rational discourse and proves irrational. This twosided opposition motivated Ajdukiewicz to coin a term comprising a somewhat "Baroque" twofold negation ("anti-" plus "irr-"). I hope to make this program clear over the course of this investigation. Thus, I see anti-irrationalism as a commitment to reason, poised to defend us against the perils of obscurity, while at the same time keeping an equal distance from any form of cult or worship of Reason, insofar as the latter refers to an alleged domain of "the right" or "the only possible" meanings (as Tarski put it); to an alleged order, or mechanism that is not tinged with the social practice of how people actually think and act. Anti-irrationalism, therefore, equals rationalism understood as a social practice of real people. However, unlike a number of more recent conceptions heading in a similar direction, e.g., the idea of ecological rationality (Gigerenzer 2008), anti-irrationalism is a genuinely normative posit: it puts on the table a certain proposal as to how we should think if we care about rationality. I must stress that it would require a separate publication to make a detailed comparison between the ideas of Ajdukiewicz and a wider group of contemporary conceptions of rationality (e.g. Searle 2001; Peacocke 2003; Kolodny 2005; or most recently Schafer forthcoming). This is beyond the scope of this paper. Here I shall only unpack anti-irrationalism as it was originally brought forth, and then focus on a certain reformulation (and generalization) of it, so as to capture a broader philosophical legacy in Poland, leaving most of the work regarding the mentioned comparisons for a different occasion.

I have been asked by the Editors of Philosophia to provide a subjective overview of Polish philosophy. Flattered by this proposal, I decided to stand up to the challenge. However, I did not plunge into writing from day one since I knew I would need a central idea that would organize the diversity of views that I would have to take into account. I am aware that the announced endeavor, drawing on the concept of antiirrationalism, may be deemed breakneck as one can hardly imagine capturing a vast diversity of conceptions developed over dozens and even hundreds of years with just one concept. However, let me point out that it is one thing to hold that these conceptions did actually realize one general regulatory idea (which obviously cannot be the case), and another to propose that we can, taking advantage of hindsight, look at the diversity in question in light of a regulatory idea. What I am about to do certainly belongs to the latter approach.

\section{Some of Ajdukiewicz's Ideas in Epistemology and Semantics, Related to the Program of Anti-Irrationalism}

\subsection{Rationalism Standing in Two Different Pairs}

Likely, the first thing that calls for clarification when it comes to the somewhat peculiar term "anti-irrationalism" is the relation in which the position so dubbed stands to rationalism, hence to a more standard philosophical label. Indeed, Ajdukiewicz's original intention was to clarify the latter by means of the former; to unpack the standard by means of the non-standard.

\footnotetext{
$\overline{{ }^{1} \text { Jedynak's (2013) characterization. }}$
} 
In the short textbook Problems and Theories of Philosophy, originally published in 1949 (English translation 1975), ${ }^{2}$ Ajdukiewicz observes that the position usually dubbed "rationalism" used to stand in two different pairs. It can be paired with empiricism, as when we investigate Leibniz versus Locke; and it may be paired with irrationalism, e.g., when Russell versus Bergson are put on the table. This specific bilocation of "rationalism" renders it obscure and the first thing to do is to clarify the terminology (for a more elaborate discussion see Ajdukiewicz 1950).

Starting from the first pair, Ajdukiewicz distinguishes Radical Empiricism (RE) which insists that there cannot be any knowledge produced by the intellect without an input from the senses, to the extent that every proposition that is supposed to contribute to our knowledge must be corroborated by what we can perceive. Now, RE is opposed to another radical position called rationalism in some circles and dubbed Radical Apriorism (RA) by the Polish philosopher. RA says that all propositions that deserve to be called knowledge are grounded solely in purely intellectual processing of data and that the data being processed originate from the intellect itself.

Now, Moderate Empiricism (ME) agrees that there is a machinery of purely intellectual processing of information, and that some truths can originate from that, yet it says that such a purely intellectual endeavor cannot produce genuinely new knowledge. On the other hand, Moderate Apriorism (MA) holds that one can produce new knowledge by purely intellectual means, but it also concedes that not all propositions deserving to be called knowledge are produced this way; i.e., MA concedes that a great deal of what we know is grounded in data collected by senses.

This seems clear and as uncontroversial as a course book description can be. Now, proceeding to the pair illustrated by Russell versus Bergson, the position that is usually dubbed "rationalism" refers to the methods we should use in order to gain knowledge. However, although we are all likely to have some inkling as to what such rationalism with respect to methods is about, it is all but obvious how to articulate it properly. And its characterization in Problems and Theories of Philosophy is negative at first, consisting in the statement that rationalism opposes overt irrationalism (hereafter IRR). This is where the term "anti-irrationalism" makes its first footprint. Rationalism understood as anti-irrationalism (hereafter AIRR) is marked out by its opposition to IRR, while the latter is characterized by distrust in our intellectual capacities. Yet, what does this distrust actually mean? IRR may say, as for example Bergson did, that our conceptual schemata are unfit to capture the internal dynamics of reality, and in effect they provide a static, thus inadequate representation of it. IRR may also appeal to the fact that empirical data, which are the basis of science, are incurably fallible, and in turn conclude that they cannot attain things themselves. In these circumstances, IRR may but it does not have to - seek to make the case that we should rather try out methods that break with the organized scientific endeavor, replacing it with some kind of private, yet thorough intuition. However, all these statements are still loose, and the fact that Ajdukiewicz includes such different figures as Bergson and Husserl in his list of proponents of IRR cannot help (by the way, Ajdukiewicz himself had attended Husserl's lectures and they were not without a certain influence on his semantic ideas,

\footnotetext{
${ }^{2}$ The book was translated by Henryk Skolimowski, a student of Ajdukiewicz, a profesor at the University of Warsaw who is regarded as one of the founding fathers of environmental philosophy (see Skolimowski 1995). The second translator was Anthony Quinton.
} 
according to Woleński 1989b). So, if AIRR is defined by its negative attitude toward IRR, and the latter can hardly be given a precise characteristic (it would be a paradox: a precise description of a position denouncing preciseness), then we don't end up with any precise idea of the former either.

Hence, we need a positive characterization of AIRR, and Ajdukiewicz, indeed, comes up with a proposal. Namely, he refers to the ideas of testability and inter-subjective communicability of rational beliefs. In order to unpack them properly, however, we need to take a brief look through his ideas in the area of semantics and a pivotal move he makes there - his undertaking of the pragmatic stance when it comes to the puzzle of meaning and, consequently, his pragmatic attitude toward rationality and rationalism.

\subsection{Ajdukiewicz'a Pragmatic Stance in Semantics}

I shall start from Ajdukiewicz's notion of meaning, a theory he developed in the early 1930s (see Ajdukiewicz 1931, 1934), as this is the domain in which his pragmatic attitude proves plausible.

On the one hand, it was clear to Ajdukiewicz, as to all the other members of LWS, that a language must be interpreted (Rojszczak 2005; more on why that was the case, see section III. 2 of the book); that investigations into formalized languages must not be conflated with investigations into purely formal (meaning non-interpreted) languages bearing no content or meaning (in this context: lacking reference to any extra-linguistic domain). The reason for it was quite straightforward: we can hardly tackle the notion of knowledge if we are armed with a plausible account of purely formal languages only, but no account of meaning. This is because at the end of the day knowledge consists of meaningful sentences or propositions.

On the other hand, a theory of meaning, if it is to be scientific (in the sense of LWS's program of "scientific philosophy"), must be based on observable facts, to avoid such problematic issues as intensional contexts, the paradox of the liar, etc.; cases that scared many philosophers away from semantics and made them limit themselves to syntax (e.g. Carnap 1934; see Woleński 1989b and Rojszczak 2005 for how the issue was approached in LWS, as well as for a more general picture).

Ajdukiewicz decided to take a pragmatic stance assuming that the meaning of a given sentence $\mathrm{E}$ belonging to a fixed language $\mathrm{L}$ can be represented as a pair composed of $\mathrm{E}$ and a set of conditions of acceptance of $\mathrm{E}$. The pair is called the meaning-rule (or sense-rule) of E (Ajdukiewicz 1931, 1934).

The basic idea laid down in this conception is that one can articulate the meaning of $E$ if one provides a description of situations in which $\mathrm{E}$ must be accepted by every competent speaker of L. Hence, the meaning of E is explicable in terms of speakers' disposition to behave in certain ways. Note, however, that Ajdukiewicz does not claim that conditions of acceptance give rise to meaning or that meaning can be reduced to behavior. The direction is opposite: it is the meaning of $\mathrm{E}$, which is assumed as primitive, that determines the conditions of E's acceptance (see Woleński 1989b).

\subsection{Three Kinds of Meaning-Rules}

Further, Ajdukiewicz distinguishes three kinds of meaning-rules for a given language L. Firstly, there are axiomatic rules according to which certain sentences must be 
accepted by any competent speaker of L, independently of their content, e.g., "A is A." In other words, their acceptance is not conditional whatsoever. The second group consists of deductive meaning-rules stipulating that acceptance of one sentence is conditional, yet still independent of the sentence's content, namely it is grounded in the acceptance of some other sentence(s), e.g., if one accepts "If A, then B" spelled out in English, and one accepts A, then one must accept B. Otherwise, one does not understand the connective "if... then..." in English, and cannot be deemed a competent speaker. Of course, it all depends on a language. The examples just given are relatively uncontroversial, since modus ponens belongs to the basic machinery of deduction, and by the same token the law of identity seems to be laid down in all cases of reasoning. But since choosing a language, at least in science, is precisely a choice, some axiomatic and deductive meaning-rules are accepted in one language and not in another.

There are also empirical meaning-rules stipulating that any competent speaker should accept certain sentences on the basis of observation. For example, if a person who is supposed to be a competent speaker of Polish refuses to accept the sentence "śnieg pada" while it is snowing, the person cannot actually be deemed competent in Polish. ${ }^{3}$

The set of all meanings in L, defined in terms of meaning-rules, establishes the conceptual apparatus of L. This conceptual apparatus, in turn, describes what Ajdukiewicz calls a world-perspective.

On this basis, Ajdukiewicz defines four kinds of languages. A language $L$ is open if can be enriched to L' by adding new meaning-rules, yet without any change in the already existing rules governing L. So, if the L part does not undergo any change as a result of being enriched to $\mathrm{L}^{\prime}$, this means that $\mathrm{L}$ is open. If $\mathrm{L}$ is not open, it is called closed. Furthermore, $\mathrm{L}$ is said to be disconnected if is there is a non-empty set $\mathrm{X}$ belonging to $\mathrm{L}$ such that the meaning-rules of $\mathrm{X}$ are not linked to any other meaningrules of $\mathrm{L}$. We can think of $\mathrm{X}$ as a somewhat separate part inside $\mathrm{L}$. If $\mathrm{L}$ is not disconnected, it is called connected. Ajdukiewicz deemed the languages employed by scientists closed and connected.

\subsection{AIRR from the Pragmatic Angle}

Insofar as people can share world-perspectives and conceptual apparatuses - and especially in science which makes use of closed and connected languages - intersubjective communication and collaborative action are possible. And, finally, this is the realm in which AIRR is provided with a positive characteristics.

Here AIRR puts stress upon the following two conditions (explicitly pointed out in Ajdukiewicz 1975):

Inter-Subjective Communicability If a given belief is purported to be rational (meaning anti-irrational), it must be communicable; it must be expressed by such means that not only the one who holds the belief understands it, but also all the other people in the community are in principle capable of understanding it. In other words, it must be spelled out in a shared conceptual apparatus and as such be part of social practice.

\footnotetext{
${ }^{3}$ It merits separate discussion whether the very idea of empirical meaning-rules relies on the acceptance of protocol-sentences, hotly debated in the 1930s (see Grobler 2013 on Ajdukiewicz in this context).
} 
Inter-Subjective Testability A candidate for an anti-irrational belief must also be testable, meaning that there must be a social practice - especially in the community of scientists - enabling people to test whether or not the belief in question is acceptable.

IRR opposes one or both of these conditions.

Now, this step into the domain of social practices ${ }^{4}$ is pivotal. Among other things, it enables us to see that AIRR is not only about the specific epistemological issue of justification and method; instead, it pertains to a broader scope of human thinking and action. In Problems and Theories of Philosophy, Ajdukiewicz himself articulates the belief that AIRR is dedicated to defending society against nonsense, especially nonsense wearing misleading philosophical apparel (e.g. pretending rationalism but in fact breaching the conditions of inter-subjective communicability and testability) and hence not so easily detectable.

In this context, Ajdukiewicz makes a good point when he says that deeming rationalism the "cult" of reason is misleading. Although he does not spell it out explicitly, the reason for its being misleading is clear - with such a characterization we would end up with a dire paradox when the assertion of reason goes far beyond reason itself toward some kind of worship which is hardly testable. I shall unpack this very interesting issue later.

\section{Broadening the Program of Anti-Irrationalism}

\subsection{Anti-Irrationalism, Meaning Rules, and Social Practice}

Faced with Tarski's criticism, Ajdukiewicz later came to the conclusion that his conception of language - especially his idea of closed and connected languages - had been a "paper fiction." (see Woleński 1989b; Jedynak 2003; Grobler 2013). However, for the purposes of this study, we can make use of the idea of world-perspective and concede that providing lists of meaning-rules of a given language $\mathrm{L}$ can at least serve as a useful partial approximation of what the world-perspective set up by $\mathrm{L}$ is.

As explicitly pointed out by Ajdukiewicz e.g. in (1950, 1964), we can reintroduce Radical Empiricism (RE) and Radical Apriorism (RA) in terms of meaning rules. A proponent of RE says that at least insofar as science is concerned, we should only accept empirical meaning-rules as explicated in I.3, i.e. acceptance of any sentence must be based on observation. On the other extreme, one who believes in RA insists that we should only accept axiomatic and deductive rules, i.e. acceptance of any sentence must be based on axioms and their consequences. Moderate positions allow for all three kinds of meaning-rules to be accepted and they differ with respect to their usability, so to speak: while ME agrees that there are plausible sentences whose meaning is defined solely in terms of axiomatic and deductive rules, it denies the possibility of producing

\footnotetext{
${ }^{4}$ Ajdukiewicz did not use the term "social practice", it is my reading. Yet, he was clear about the fact that science is a social endeavor. He writes for example: "We are confronted with science as an empirical fact, historical and social in character. In the history of mankind, it grew out of the practices of tribal magicians and sorcerers, from the speculations of philosophers and from the experience of practical life; its beginnings are difficult to delineate. Today, however, it appears distinct enough, though its limits are still blurred and will probably always remain so". (Ajdukiewicz 1963; quoted from Ajdukiewicz 1978: 296)
} 
genuinely new pieces of knowledge based on them. On the other hand, MA accepts empirical meaning rules, yet it also insists that there are sentences conveying genuinely new knowledge whose meaning does not draw on observation.

Ajdukiewicz himself suggests in $(1964,1975)$ that AIRR allies with ME (see Woleński 1989b). On the other hand, he evolved over the years much closer to RE and it is not clear how this move was related to the issue of AIRR. Now, although I see no reason to openly disagree with the reading associating AIRR with ME (or RE), I would like to propose something else. And I argue that it is not at odds with Ajdukiewicz and LWS.

I shall make use of the notion of world-perspective, assuming that its sense is given. So, firstly, I propose that AIRR is not a particular position, but rather it operates as a meta-level decision platform and provides tools and criteria enabling one to build and/ or choose a world-perspective; even if not to pick one in a flash, then at least to eliminate some options.

The importance of the notion of choosing and/or building a world-perspectives proves crucial once we realize that according to Ajdukiewicz (1934; see also 1949), empirical data cannot force a scientist to accept or reject any sentence (insofar as the language of science is closed and connected): if there is inconsistency between the data and the sentence, one can always change the conceptual apparatus, thus change the worldperspective. This position is called radical conventionalism. This form of conventionalism differs from the one endorsed by Poincaré in one crucial respect: while Poincaré targeted a priori structures that we impose on the empirical facts as conventional (his view was primarily focused on geometry), Ajdukiewicz's radical conventionalism targets facts as well. This means that we have no access to facts outside a particular language; any delineation of facts, as it were, depends on a conceptual apparatus.

Therefore, being true or false can be sensibly ascribed to a sentence, according to Ajdukiewicz, only within a given world-perspective, so that one never has an isolated sentence to be compared somehow with reality itself, but each such "comparison," if possible at all, takes place within a given framework established by a fixed conceptual apparatus. This leads to the question of how a world-perspective as a whole is related to reality itself (see Ajdukiewicz 1934a, 1949).

Now, on the basis of radical conventionalism it makes no sense to hold that a worldperspective as a whole is true or false. A somewhat Kantian whiff of this conception is that all our cognitive efforts refer to phenomena and we are unable, as already pointed out, to get a glimpse of reality itself. It seems then that world-perspectives are constructions that one can either accept or reject, employ or not, en bloc. ${ }^{5}$ At the end of the day the question is not whether a particular world-perspective is true but why it is

\footnotetext{
5 Perhaps there is also some affinity between Ajdukiewicz's view and Thomas Kuhn's idea of paradigms. Note that Kuhn (1962: vii) himself referred to another Polish philosopher and scientist from the 1930s, yet not a member of LWS, namely Ludwik Fleck (1935) and his conception of styles of thinking which anticipated Kuhn's conception (see e.g. Cohen and Schnelle 1986; Sady 2017). Sady (2017) notes “Today, in the English speaking world, Fleck is mostly considered to be an unappreciated forerunner of Thomas Kuhn's theory of scientific revolutions. It is in the German speaking community of philosophers and sociologists of science that Fleck is considered to be a highly original epistemologist, who presents human knowledge in a quite peculiar and explorative way which significantly transcends Kuhn's theses. In France there is a group of philosophers and historians of medicine - Ilana Löwy and others — who apply Fleck's ideas in their research. In his famous introduction to the actor-network theory, Bruno Latour named Fleck 'the founder of sociology of science' (Latour 2005, p. 112). In 2005 Ludwik Fleck Zentrum was founded in Collegium Helveticum, Zürich (...).”
} 
accepted by a given community or, perhaps, in some special situations, by an individual; why people assert a particular perspective.

Note that this pragmatic angle makes the question of rationalism and irrationalism pivotal: unlike truth itself which is in principle independent of what we think and could even be adequately grasped by accident (as Gettier's 1963 examples show), what really matters here is how we come to decide which perspective we pick up. Thus, we find ourselves in a situation in which the burden is placed on the tools, methods, criteria and even attitudes that are supposed to guide the activity of constructing and/or choosing a world-perspective. And as we are about to decide whether or not to accept a given world-perspective, we need to defend ourselves against nonsense, thus against irrationalism of any sort.

So, when it comes to the announced notion of decision platform, I propose that the AIRR - IRR distinction is in the first place about how we build a world-perspective; about the "tools" we use to fulfill the task. Roughly speaking, we can follow both ordinary and scientific social practices, e.g., by allowing all three kinds of meaning-rules to be employed, or we can break with the social practice, limiting people's epistemic practices and therefore calling for a sweeping reform of how humans build knowledge, e.g., by allowing only one or two kinds of meaning rules (as it is the case in RE and RA).

So, I propose that in this context AIRR insists on staying true to actual social practices, whether in science or everyday life. This means that any a priori restriction imposed on these practices deserves to be called irrational; it belongs to IRR. This does not mean that the social practices are deemed perfect, indefectible. Of course they are imperfect, yet the point is that it would be of no benefit to make armchair decisions as to which types of commonly practiced ways of obtaining knowledge should be dismissed upfront.

When generalized, this reading of Ajdukiewicz's AIRR is deeply non-trivial. Remember his idea of AIRR's duty to defend society against nonsense. This is the first point at which we can recognize the possibility of there being positions that call themselves rationalism and yet, paradoxically, are saddled with irrationalism. This happens when the reason (or Reason) invoked as the source of standards for the real people's epistemic endeavors has nothing to do with these people's actual epistemic capacities, goals, and perspectives.

In this context, IRR stands for any artificial restriction imposed on actual social practices from "outside," as it were. Such a restriction would mean imposing a standard, a goal or an ideal that ignores how real people, including real scientists, real decision-makers, lawmakers and others gain their knowledge, solve problems or behave. ${ }^{6}$ However, this is only the first step.

\subsection{Anti-Irrationalism, Scientism, and Mythical Thinking}

Hence, we have two strategies: one follows both ordinary and scientific social practices, e.g., allow all three kinds of meaning-rules to be employed (this is the AIRR strategy),

\footnotetext{
${ }^{6}$ In this context, it would be plausible to bring in one of the most interesting arguments developed by Ajdukiewicz, namely his semantic argument against transcendental idealism, primarily as formulated by $\mathrm{H}$. Rickert (Ajdukiewicz 1937; also Küng 1988; Chrudzimski 2016). Unfortunately, there is no place in this paper to do that.
} 
whereas the other group breaks with the social practice and restricts the range of meaning-rules employed (which is targeted here as the birthmark of IRR).

However, now I wish to argue that one can avoid the said kind of IRR, yet still end up with IRR of some other sort insofar as the chosen world-perspective' very being chosen is forgotten. The latter IRR is not about how we build a worldperspective; rather it pertains to a special attitude we take toward the constructed/ chosen one. Perhaps that is what some thinkers mean when they invoke "scientism," referring to the unwarranted extension of the methods of science and its pretence to objectivity to all domains of enquiry and life (e.g., Hayek 1980). In effect, science is deemed the only plausible story about the world. This possibility of IRR pertaining to a domain that may be regarded as the paradigmatic realization of AIRR, i.e., science, is a persistent source of confusion. To put it simply: how can one be irrational about one's own exercise of rationality? I believe that Ajdukiewicz's framework, interpreted in the way rolled out here, can do a good job in eliciting this complex and, indeed, surprising structure of our attitudes.

For the sake of this interpretation I bring Leszek Kołakowski, another recognizable Polish philosopher (not a member of LWS, however, an assistant to Kotarbiński), who started out as a fierce defender of Marxism in the 1940s and 50s, but ended up as one of its most influential and well-recognized critics (see Kołakowski 2008), which would lead into exile from 1968 (he would become a fellow at All Souls, Oxford, and at the University of Chicago).

Kołakowski was a philosopher and a historian of ideas (he contributed to the establishment of the Warsaw school of the history of ideas), tracing all remnants of mythical thinking in modern secular culture, philosophy, ideology, politics, and science (or rather in thinking about the sciences). It turns out, I propose, that IRR can be seen as a sort of mythical thinking and, surprisingly, it can turn up also in the guise of a mythologization of reason and rationality, including science.

In his seminal work, The Presence of Myth Kołakowski (1989) uses the term "myth" in a somewhat less technical sense, distancing himself from the way in which historians of religion appeal to myths, yet investing the term with a characteristically abstract philosophical character. Kołakowski purposely does not provide any strict definition of myth upfront, hoping that his usage of the term can be read from the contexts he addresses, but a sort of basic characterization of mythical thinking is suggested in the preface. Namely, a myth is any intellectual construction that purports to bind "conditioned and mutable elements of experience" with alleged "unconditioned realities (such as 'being,' 'truth,' and 'value')" (Kołakowski 1989: ix). I propose to read it in a way linking us nicely with Ajdukiewicz: our world-perspectives are constrained and limited by our conceptual apparatuses, but also points of view, sensory apparatus, and a variety of other factors; thus they are - to use Kołakowski's vocabulary conditioned. Conditionality, i.e., being sensitive to a given language, context, tool, etc., is the hallmark of each world-perspective.

Now, mythical thinking, which is not thought of by Kołakowski as something bad, by the way, but as an indispensable aspect of every human endeavor, envisages a prospect of there being somewhere, behind a veil, a domain that is not conditioned in any way (like Plato's ideas) and a prospect of getting in touch with this domain. Hence, mythical thinking is an attempt to overcome the limits of all world-perspectives and to reach the unconditioned realm. 
Among the myths we eagerly create and consume there is the myth of Reason. Kołakowski writes:

Thus, truth as a value different from effective applicability is therefore a part of myth which refers the conditional empirical realities to an unconditioned universe. It is part of the mythology of Reason, which establishes the discontinuity between Reason and the biological assimilation of the world and therefore does not wish to regard Reason as a bodily organ. If the brain is part of the body, and reason a part of the brain's behavior, epistemological valuation cannot be saved; truth cannot be saved as a quality different from technological applicability; nor can the rules of logic as a code discovered by the thinker in the nature of thought.

We need the myth of Reason to have the belief that our logic is not simply a savoir vivre of a community cooperating in thought, nor only a physical property of our bodily constitution or of our way of speaking (Ibid.: 41).

Here is the sought connection between Kołakowski's reflection and Ajdukiewicz's posit: from the perspective just unpacked, it could be said that AIRR seeks rationalism that is free from the myth of Reason and all its embodiments, such as the myth of the ultimate truth serving as the ideal of our epistemic efforts, or - going back to the issue of scientism - the myth of science as unveiling reality in itself, unconditioned by our cognitive limitations. AIRR is supposed to give justice to reason and even praise reason without an attempt to transplant our conditioned, conventional grasp of it into an alleged unconditioned realm in which reason becomes Reason.

It turns out that Rationalism understood as a sort of worship of an alleged Reason or Rationality is, in fact, an exercise of IRR. I propose, therefore, that in this context, AIRR is, first of all, the awareness that the chosen world-perspective is a worldperspective, while IRR boils down to the belief that the chosen world-perspective is identical to reality. In other words, IRR is a kind of dogmatism, whereas the core of AIRR is the acknowledgement of the very fact that there may be different worldperspectives, and even if the asserted one satisfies all of our conditions, it is still only $a$ perspective. This means that even the perspective praised as the best available at $a$ given moment is still one of many possible perspectives. Hence, when it comes to the invoked case of scientism, it is rational in the sense of AIRR to choose science as the right source of knowledge about reality, and irrational to forget about that choice's being $a$ choice.

\subsection{Anti-Irrationalism with Respect to Conditions}

Another thing is to make sure that the conditions employed when choosing a given world-perspective (or an attitude toward the chosen one) satisfy AIRR and avoid IRR. Note again the difference: even if you acknowledge that each world-perspective is $a$ perspective, thus a matter of choice, you can still end up with another kind of IRR, namely the one pertaining to the conditions followed in making the choice. To summarize: there are tools one uses to built/choose a world-perspective; there are attitudes toward the constructed/chosen world-perceptive; and finally there are conditions or criteria that one employs to make the choice. And at each stage, one can stick with AIRR or succumb to IRR. 
Here, at the level of criteria or conditions, I see the place for Ajdukiewicz's notions of inter-subjective communicability and inter-subjective testability. The idea is that if you want to safeguard your choice of a particular world-perspective from IRR, you have to able to communicate your reasons in a public language so that other people can understand them. Even if the latter requires mastery of some technicalities, it must not be some obscure method in principle inaccessible to the vast majority of people. Secondly, your reasons must be testable, meaning that if you rely on empirical findings, your observations must be repeatable in a similar, experimental or natural setting; and if you rely on a chain of deductive steps, you must define the exact rules you used and axioms you accepted, if any, so that others can follow your train of thought.

\subsection{Three Kinds of IRR and AIRR: a Summary}

To sum up, I propose that there are three levels of the IRR - AIRR distinction.

- IRR - AIRR with respect to the "tools," broadly construed, primarily meaning-rules (which is what Ajdukiewicz was originally focused on), employed to build worldperspectives. IRR equals an artificial restriction within the types of tools, while AIRR reflects the actual social practice by allowing all of them at the starting point, leaving room for further decisions as to the scope of each tool (e.g., each meaning-rule).

- IRR - AIRR with respect attitudes towards the built/chosen world-perspectives. Here a proponent of IRR (likely, unaware of their attitude) picks one particular perspective and, in a sense, forgets about the choice just made, treating the chosen world-perspective as identical to reality. AIRR is "merely" the awareness of the fact that the choice made is $a$ choice; that the perspective picked up is $a$ perspective which is never identical to reality. IRR as it stands here can be referred to as some kind of dogmatism.

- IRR - AIRR with respect to the conditions governing the choice of a worldperspective. One has to be ready to provide reasons for choosing a given worldperspective, and in order to count as belonging to AIRR these reasons must be spelled out in a way that in principle everybody can understand and based on data that in principle everybody has access to. Otherwise, we end up with IRR.

\subsection{Anti-Irrationalism About Anti-Irrationalism}

There is one more thing that should be said. As I mentioned at the beginning, rationalism understood as anti-irrationalism cannot be deemed the "cult" of reason because it would produce a plain contradiction: the assertion of AIRR would breach the conditions of AIRR itself. I therefore propose to render AIRR a recursive or selfreferring attitude. This means that each articulation of AIRR must satisfy the conditions of AIRR, i.e., in the first place, it must itself be communicable and testable.

One might ask what it could mean for AIRR itself to be testable. Here is what I mean: AIRR must be proven actually useful in each particular case. Let us take quite a controversial example: suppose that Sam and John are debating on the issue of gun laws in the United States. And here comes Jane who says that they should examine what justifies their beliefs in step with AIRR, i.e., to examine their claims' inter- 
subjective communicability and inter-subjective testability (e.g. do they really communicate with each other when they seem to be using the same the term "Second Amendment"?). The point is that Jane herself has to be able to communicate, i.e., to explain in an understandable way and "prove" why Sam and John will benefit from employing the mentioned conditions. Now, the notion of "understandable way" appeals to social practices and natural language as they actually exist in a given community. Hence, this requirement forces Jane, who might be, for example, an academic, to articulate her point in the usual terms, without the technicalities specific to her discipline. And to "prove" of course refers not to a proof in the proper sense of the term, but rather to an exposition of practical results or of other cases in which the AIRR strategy has already proven useful, so that Sam and John can actually see that employing AIRR may be of some use to them. The AIRR strategy may be recognized as trustworthy more or less along the same lines as engineers' expertise is trustworthy based on the fact that they build bridges that don't usually collapse: one does not have to be an expert in all the computations required to make the bridge firm in order to examine its firmness.

The purpose of making AIRR self-referential or self-sensitive is primarily related to social issues. The purpose is this: expecting each articulation of AIRR to satisfy the conditions of AIRR prevents us from a situation in which there is a gulf between people professionally engaged in certain discursive pursuits (members of academia, journalists, lawmakers and the like) and people for the benefit of whom the former group is supposed to work. This is related to more general debates going on in contemporary epistemology pertaining to the role of experts and what it actually means to rely on someone's expertise. There is a risk of experts being effectively locked up in what Thi Nguyen (2018) has recently called cognitive islands, i.e., domains of expertise that require one to be an expert or at least a person familiar with the domain in order to grasp it. Cognitive islands are actually inaccessible to profanes. Hence, AIRR can likely be considered a means of defending society against the perils of cognitive islands.

\subsection{A Modern-Day Limitation of Ajdukiewicz's Concept of AIRR}

The appeal to the issue of cognitive islands draws our attention to a certain limitation built into Ajdukiewicz's original rendering of AIRR in terms of inter-subjective communicability and testability; one that has only recently come to the fore thanks to technological development and, as such, could not have been known to Ajdukiewicz. It seems that appealing to inter-subjectivity may not be sufficient to guarantee that someone will not succumb to IRR in the specific context of what is known today as the filter bubble, information cocoon or echo chamber (see Pariser 2011; Flaxman et al. 2016). These constructs can be considered flip sides of cognitive islands, i.e. as opposed to experts' being isolated on their cognitive islands, filter bubbles are realms of data and beliefs that are usually immune to expert knowledge. Think for example of the belief that Barack Obama was not born in the United States, held by some in the United States. A priori it is possible that this false belief passes the standard AIRR test if one's social media and other communication channels are structured in a particular way by algorithms responsible for creating psychometric profiles, to the effect that one can find other individuals whose communication channels are tuned in a similar way, and they can easily communicate within their shared information cocoon or even run 
some "tests," thereby finding lots of "data" to support their belief in the conspiracy launched by Mr. Obama to hide his true birthplace (I am not saying that such a technology is available now, yet it is a thinkable option; see Matz et al. 2017).

The information cocoon can hardly be accounted for in Ajdukiewicz's original terms, yet it can be approached as a certain pathology of the world-perspective, meaning a perspective whose task to select means or channels for reaching out to the world (knowing the world) has been replaced with the task of blocking these very channels. Hence, we have to amend the understanding of AIRR with respect to conditions provided above.

Of course, the filter bubble created by those who believe in the Obama conspiracy cannot count as a complete or comprehensive world-perspective. If so, one might argue that the issue of information cocoons does not constitute a thread to Ajdukiewicz's, or an Ajdukiewicz-inspired, account of rationality. I shall not make a strong case for why we should think otherwise as this is not the proper topic of this paper. However, one thing that could justify invoking filter bubbles in this context is their systematic character, as it were, meaning that they are not just momentary exercises of our irrationality which can be corrected easily by relevant data (like Obama's birth certificate); instead - they are relatively stable structures, based on countless pieces of statistical information pertaining to our behavior and constraining our access to the relevant data. If so, it seems that their impact on our cognition may be more fundamental and long-lasting, thereby shedding new light on the issue of rationality, too.

In this situation, we need to reintroduce the IRR vs. AIRR distinction with respect to conditions or criteria in newer terms, so that it can accommodate individuals who may be locked up with others in shared information cocoons, deceitful as these can be, for they create an illusion of inter-subjectivity, thus an illusion of rationality.

The problem just brought up does not pertain to Ajdukiewicz's conception only. J. Searle writes in his classic book Rationality in Action:

Rationality in action is that feature which enables organisms with brains big and complex enough to have conscious selves, to coordinate their intentional contents, so as to produce better actions than would be produced by random behavior, instinct, tropism, or acting on impulse. $\left(2001\right.$, p. 141) ${ }^{7}$

Note, however, that the man who believes that Barack Obama was not born in America can satisfy such a mild description of rationality. He can coordinate his intentional contents with some of his fellow believers and produce better actions than would be produced by him alone. As a coalition they can establish a political interest group and influence the democratic process. After all, there is no a priori limitation imposed on what can count as a better action or as a good outcome of action. So if the group can influence the democratic process, it's good for them, at least from their constrained perspective.

The point is that we can hardly denounce their belief as plainly false - even if it is false if we don't want to succumb to IRR by believing that we, unlike they, enjoy some

\footnotetext{
${ }^{7}$ It has become somewhat fashionable recently to examine human cognitive capacities against the background of the environments in which they evolved; see e.g. Gigerenzer (2008) who places his conception of rationality against the background of Tversky and Kahneman's 1974 theory which is widespread especially among economists.
} 
privileged glimpse of reality. Someone might argue that in the cases such as " $\mathrm{X}$ was born in Y" there are documents that can be easily checked. ${ }^{8}$ However, our access to documents is always part of a world-perspective, therefore, as noted, it may be constrained by the pathologized world-perspective; i.e. our filter bubble. Hence, we need to appeal to some conditions that the group failed to satisfy when constructing their world-perspective, not to truth thought of as correspondence with reality itself. But what conditions?

I propose to translate inter-subjective communicability into cross-perspective communicability, meaning that each factor that you are going to use as a building block in your world-perspective must in principle be explicable and understandable to someone living in a different world-perspective. If you and your friends construct a shared world-perspective, you have to be able to explain to someone who does not partake in your endeavor why a given tool, datum, or material deserves to be used. Analogously to Ajdukiewicz, who put stress on the possibility of understandable communication between two people, here the stress is put on understandable communication between a group of people sharing one world-perspective and another group sharing a different one. This condition does not allow the former group to be caught up in a bubble in which they in fact exercise fake communication.

Furthermore, following Ajdukiewicz again, each part of one group's worldperspective should in principle be testable by the members of another group, thus for every factor constraining one world-perspective there must be a possibility of reproducing it in a different world-perspective so that it can be examined. For example, when one group of people sets forth a conspiracy theory about Mr. Obama, each part of the theory must be examinable by a different group of people.

Now, the point about AIRR's self-reference and the proposed amendment of Ajdukiewicz's conditions of AIRR will prove crucial in the last, most speculative part of this paper which maximally broadens the very idea of anti-irrationalism, so that it can be applied to societies, states, political powers, etc. However, since the announced generalization of AIRR is, as I said, maximal, it requires some preparation. Hence, the thing I am about to do in the third part of the paper is to recognize Ajdukiewicz's closest environment, i.e. the Lvov-Warsaw School (LWS) in the light of AIRR.

\section{Anti-Irrationalism and the Legacy of LWS}

\subsection{Acts, Products, and the Lvov-Warsaw School}

In this second part of the paper I come back to the context that gave rise to the ideas discussed in the first part. The goal now is to use the somewhat generalized idea of antiirrationalism that emerged in the first part, and to recognize it as a characteristic feature of the legacy of LWS.

Ajdukiewicz himself in (1935) regarded the label "anti-irrationalism" as an apt summary of the spirit pervading Polish philosophy in the first three decades of the twentieth century, or at least the part of it that was under the influence of LWS. AIRR is therefore first and foremost the birthmark of the Polish branch of the twentieth-century analytic movement. At the beginning of the paper I sought to grab the attention of the

\footnotetext{
$\overline{{ }^{8} \mathrm{I} \text { thank an anonymous reviewer }}$ of this paper for bringing up this argument.
} 
reader by promising an explanation of why it was so natural for Tarski to tackle the problem of truth, and I suggested that AIRR had something to do with it. I shall now say something more about this issue.

LWS was established in the late nineteenth century in Lvov (Polish "Lwów"; now in Ukraine), ${ }^{9}$ by Kazimierz Twardowski, who completed his doctorate in Vienna, influenced in the first place by Franz Brentano. ${ }^{10}$ Having accepted a position at the University of Lvov, he began organizing a school of "scientific" philosophy, as he envisioned it (Twardowski 1999; see also Smith 1989; van der Schaar 2015; Betti 2017). Although the university enjoyed a long tradition going back to its establishment in 1661 by the Polish king John II Casimir Vasa (Polish: Jan II Kazimierz Waza), there was no significant philosophical concentration when Twardowski arrived.

There were two ways of achieving the goal of rigorous theorizing in Twardowski's school. Both of them appealed to language analysis, which was more or less in step with the tendencies emerging at that time elsewhere, too. The first route, taken by Twardowski himself, drew on Brentano-style descriptive psychology and was realized over the course of diligent analysis of expressions from natural language. The other route, taken by an early student of Twardowski, Jan Łukasiewicz, drew on developments in logic, and hence focused on formal languages. Łukasiewicz would later come up with the very first systems of multi-valued logic (see Łukasiewicz 1970; see also e.g. Cignoli 2007). He also invented so-called prefix notation, also known as Polish notation which was initially a parenthesis-free formalization of expressions in sentential calculus, and would later become popular in programming due to its application in the popular programming language Lisp.

Twardowski inherited from Brentano the view according to which intentionality, i.e., being directed toward an object is the mark of the mental. However, according to Twardowski, there is a difference between intentionality of acts and intentionality of their products (see Twardowski 1999). The general distinction between acts and products was based on a grammatical distinction, which was however used to show certain logical and indeed ontological differences (see Woleński 1989b, 2002; Rojszczak 2005; Betti 2017). For example, there is a difference between running and run; judging and judgment; speaking and speech; painting and a painting.

Now, taking these two ideas together, for Twardowski the crucial thing was the distinction between mental, thus intentional acts or processes producing certain contents, and these very contents thought of as products; products that inherit the intentionality from the acts, yet - unlike the acts - are subjected to logical analysis.

Among types of products Twardowski listed so-called psycho-physical ones which resulted from thinking, imagining or some other mental activity, yet were preserved by some kind of physical structure, be it a painting or a written sentence. Taking Brentano's groundbreaking posit and Twardowski's distinction together, aside from

\footnotetext{
${ }^{9}$ The history of this part of Europe is extremely complex and tangled from the perspective of an outsider. Lvov is a city within the boundaries of the land traditionally known as Kievan Rus' which present-day Ukraine harks back to. However, from that period it has undergone many geopolitical shifts, becoming part of the Kingdom of Poland, the Polish-Lithuanian Commonwealth, the Russian Empire, and from 1918 to 1939 again part of Poland. After World War II Lvov was in the Soviet Union and is now in Ukraine.

${ }^{10}$ Twardowski is rightly regarded as a student of Brentano, however, since Brentano had resigned from his chair in 1880, Twardowski's supervisor was Bolzano's pupil Robert Zimmermann; see Brożek 2011; Betti 2017.
} 
other products, there are linguistic expressions which are products of intentional acts and, as such, inherit, conserve and convey the initial, original intentionality of mental acts so that it can be part of a larger structure of language and knowledge.

And this is the understanding that Tarski associated with the notion of the sentence (see especially the seminal book by Rojszczak 2005), an understanding that made room for nominalism with respect to sentences, thus avoiding Platonism and treating sentences as concrete, physical objects manipulated at the syntactic level, while at the same time maintaining the idea that a sentence is essentially about something (that it is interpreted in some extra-linguistic domain). Thus, the sentence as a product, due to the fact that it inherits intentionality from the mental acts that produced it, is a perfect candidate for an entity that can be manipulated in purely formal ways and at the same time having a properly semantic aspect: the capacity to refer. In this sense, according to Woleński and Simons (1989) and Rojszczak (2005), Brentano-Twardowski's foundation of LWS laid the groundwork for the semantic definition of truth and for the pursuit of formal semantics developed by Tarski when already at Berkeley. ${ }^{11}$

\subsection{LWS' Metaphilosophy}

The idea of psycho-physical products makes room for abstract analysis - be it logical or philosophical - not imperiled by psychologism, i.e., the reductionist claim that all that can be said about thinking, language, cognition, knowledge etc. boils down to claims about mental processing. On the other hand, grounding these analyses in psychophysical products does not allow for treating language, knowledge, and the whole sphere of meanings and ideas as completely detached from real people's actions and social practices. Hence, the LWS approach highlights the relative independence of meanings and ideas but at the same time bans any attempt to invest this intellectual and normative space with a mythological flavor, treating it as part of an alleged Reason or a somewhat Hegelian objective spirit. Meanings must be bonded to social practices, inheriting all the limitations of the latter. ${ }^{12}$

This, in my reading, explains why Tarski ${ }^{13}$ distanced himself from traditional philosophical debates, while at the same time not shying away from tackling one of

\footnotetext{
${ }^{11}$ In this context, it is also worth noting that Twardowski's act vs. product distinction is being revived these days in certain branches of natural language semantics (see Betti 2017).

${ }^{12}$ I do not argue that there was one canonical understanding of language in LWS, shared by all members of the school. However, following Rojszczak (2005) in the first place, I hold here that the notion of psycho-physical products set the stage, as it were, for the plurality of views developed in LWS. Tadeusz Kotarbiński's nominalism, as unpacked by Woleński (1989), provides a nice illustration of this fact. Woleński lists some of the major troubles that all kinds of nominalism in the philosophy of language must face, and then adds: "I do not think that Kotarbinski was fully aware of those troubles. I would risk the guess that those troubles were to some extent camouflaged by the theory of meaning intention, which Kotarbinski accepted together with other philosophers of the Lvov-Warsaw School, perhaps not in Husserl's version, but rather in that of Brentano and Twardowski. While philosophers like Ajdukiewicz could freely exploit the distinction between mental actions and objectified products (...) because they were not bothered (rightly or not) by the ontology of those products, the acceptance of that distinction by Kotarbinski is a puzzle in the light of the assumptions of reism." (Woleński 1989: 263). Woleński's point about the "camouflage" interestingly points to the fact that the legacy of Brentano and Twardowski had an impact also on those parties within LWS that did not necessarily share all of the founding fathers' views about intentionality and content.

${ }^{13}$ Let me stress that it is not my ambition to provide an interpretation of Tarski's metaphilosophy. He stands here solely as a representative of a more general metaphilosophical spirit characterizing LWS.
} 
their major subjects - the question of a proper definition of truth. It also explains the special approach to philosophical investigations shared by most of the thinkers associated with LWS.

Here is my reconstruction of the argument which, I believe, does justice to the antiirrational spirit of LWS. To begin, members of LWS distanced themselves, as the Vienna Circle did, from pursuits within more traditional philosophies that struggle to unveil the alleged true meaning of this or that concept, be it truth, beauty, being, substance or knowledge; thus from what I provisionally call philosophical exclusivism. This is the point where Tarski writes:

In fact, it seems to me that the sense in which the phrase "the right conception" is used has never been made clear. In most cases one gets the impression that the phrase is used in an almost mystical sense based upon the belief that every word has only one "real" meaning (...), and that all the competing conceptions really attempt to catch hold of this one meaning (...) (Tarski 1944: 355)

However, Tarski's criticism can also be applied to those seeking an ultimate sense and scope of the concept of philosophy to the effect that "the right conception" of philosophy, as projected by the Vienna Circle, can also be "used in an almost mystical sense."

Therefore, maintaining AIRR, LWS is also against what I would call, by the same token, metaphilosophical exclusivism which is dedicated to nailing down the proper scope of philosophy once and for all. Here is my reconstruction of a very straightforward argument that members of LWS could have in mind: note the following trivial fact, namely that people do philosophize. Doing philosophy, thought of as asking the most general questions targeting the overall architecture of the world, cognition and life, has been one of man's pursuits since at least ancient times. So - the argument continues - it would be irrational to oppose this deep-seated social practice by imposing some artificial limits on what can sensibly be a target of human reflection. In this respect, LWS differs significantly from the Vienna Circle which was strongly exclusivist in its metaphilosophy.

The point made by LWS, in my AIRR-reading, is that both exlusivisms forget the act vs. product distinction, treating abstract concepts as if they were not products of actual people's thinking. Both of these exclusivisms turn out to belong to IRR in their refusal to "reconcile ourselves with the fact that we are confronted, not with one concept, but with several different concepts which are denoted by one word" (Tarski; Ibid). ${ }^{14}$ In this light, the neopositivist abandonment of a large set of traditional philosophical problems refuses to "reconcile ourselves with the fact" that people are considering these problems; that they do care about these problems, etc.

\subsection{The LWS Environment}

This rigorous, yet open-minded approach gave rise to a significant diversity of achievements in logic and philosophy. Going back to history for a moment, another important

\footnotetext{
${ }^{14}$ Naturally, the rejection of the two exclusivist paradigms is just a regulatory idea, actually realized in different manners and to differing degrees by different thinkers, yet this, in my opinion (which is in step, if I am not wrong, with the accepted way of reading of LWS metaphilosophy; see Woleński 1989), is an apt description of the overall spirit within LWS, combining rigor with respect to methods and open-mindedness with respect to the subject matter of philosophy.
} 
date is 1918, when Poland regained independence after 124 years and the University of Warsaw was reopened (actually, it was already reopened during the Great War, in 1915). Łukasiewicz, whom I already mentioned, together with Stanisław Leśniewski, another logician and a student of Twardowski in Lvov, were appointed professors in Warsaw, but interestingly - at the mathematics department. This created an environment for collaboration between mathematicians - working at that time in Poland primarily in areas of great philosophical importance such as set theory - and philosophers. Leśniewski has gone down in history as the founder of mereology, i.e., the formal theory of parthood relation (see e.g. Simons 1987). He also invented two other formal systems known as ontology and protothetics. He would later become the supervisor of Tarski's doctorate (see Leśniewski 1992). The group of logicians included also, among others, Stanisław Jaśkowski, Adolf Lindenbaum, Andrzej Mostowski, Jerzy Słupecki, Moses Presburger, Bolesław Sobociński and Mordechaj Wajsberg.

Of philosophers clearly associated with the analytic movement, the most important ones were likely Ajdukiewicz and Tadeusz Kotarbiński, a proponent of a radically nominalistic ontology known as reism, and a co-founder of praxeology, a specific theory of action (see Kotarbiński 1968; also e.g. Niiniluoto 2002, Zaręba 2017).

Interestingly, the spirit of rigor and open-mindedness pervading LWS did not attract analytic philosophers and logicians only, but also a number of historians, art theorists, psychologists, aesthetics scholars, and social scientists, who also flocked to Twardowski's school (see Woleński 1989b). And, last but not least, there was a significant number of figures who were not part of LWS, but still stayed within its orbit in different ways. A good example is Roman Ingarden, initially a student of Twardowski, who would later move to Germany (and distance himself from LWS) to study under Husserl and then, back in Poland, establish his position as one of the most significant members of the phenomenological movement. His main work is Controversy over the existence of the world (Ingarden 1964), while he is most remembered worldwide for his ontology of the artwork (Ingarden 1979; see also e.g. Thomasson 2017). He had a small group of students at Jagiellonian University in Krakow in the 1950s and 1960s, despite political pressure from the communist regime, including, among others, the analytic philosopher and historian of LWS, Jan Woleński (b. 1941), the logician and ontologist Jerzy Perzanowski (1943-2009; see Perzanowski 2012), and the Catholic ethicist and philosopher of dialogue Józef Tischner (1931-2000; see e.g. Tischner 1984).

From an entirely different angle, the members of LWS also took part in the broader cultural life of their time, which was nicely described by S. \& A. Feferman in their biography of Tarski (Feferman and Feferman 2004), teaming up with such figures as e.g., Stanisław Ignacy Witkiewicz (vel Witkacy), painter, art theorist, ground-breaking playwright (see Witkiewicz 1969, 1992) and, last but not least, philosopher; or Leon Chwistek, a logician and a painter by training, and a philosopher, original in all of his professions, who maintained some connections with LWS but did not enter the school (see Linsky 2009).

The outbreak of World War II in 1939 brought an end to LWS considered as an organized, coordinated intellectual movement (see Woleński 1989b, 1995). Some of LWS's members would continue their work after 1945, in Poland or abroad, nonetheless a great number of them would not survive German occupation of Poland. Twardowski and Leśniewski died just before the war, in 1938 and 1939, respectively. 
Lindenbaum was shot together with his sister in 1941 on the outskirts of Vilnius (see Zygmunt and Purdy 2014). Presburger was murdered in the Holocaust probably in 1943 (see Zygmunt 1991), while the place and time of Wajsberg's death is completely unknown; we only know that he did not survive the war (see Surma 1973). Tarski, Łukasiewicz and Sobociński were among those who emigrated (to Berkeley, Dublin, and Notre Dame, respectively). Ajdukiewicz, Kotarbiński, Mostowski and Jaśkowski ${ }^{15}$ contributed significantly to the restoration of academic life after the war. The latter was possible, among other factors, thanks to the system of clandestine education organized by Poles during the war, comprising high schools and universities.

Another thing that should be mentioned is the fact that LWS included many Polish Jews. Most well-known are, of course, Tarski, Lindenbaum and Presburger. Tarski once said (personal communication as noted by H. Hiż; see Woleński 1995) that religion divides people while logic brings them together, and this was clearly exemplified by LWS. Woleński (1995) rightly stresses that we can replace "religion" with "ideology" in this context. Admittedly, Łukasiewicz, Leśniewski and Sobociński privately expressed opinions that strike us today as clearly antiSemitic (see Woleński 1995). At the same time, they were able to successfully engage in collaborative efforts with, and praised the scientific achievements of, Tarski and others. Kotarbiński, on the other hand, was deeply engaged in the opposition to anti-Semitism in 1930s (see Woleński 1990).

There is a legitimate question as to whether or not the anti-Semitism of some members of LWS influenced their philosophy, and - on the hand - whether or not the philosophy had any impact on the behavior of the people in question, especially during the horrors of WWII. My position is that there was no relationship between personal attitudes and philosophy or logic proper, meaning certain abstract theoretical constructions. My reason for this belief stems from the fact that LWS had no visible ideological affiliation whatsoever. Anna Brożek writes in this context:

A philosophical school is usually characterized by some shared views. This is not the case with the LWS. Members of the School were very varied from the point of view of philosophical positions, as well as with respect to political convictions, attitudes towards religion, nationality, etc. They counted among them nominalists and realists, priests and atheists, socialists and conservatives, Poles, Ukrainians and Jews.

So, what - besides the common roots in Lvov and Twardowski as a mentor-was the reason for calling such a group "a school"? The reason was that all members of this group shared a methodological position. This position may be characterized, most generally, by two postulates: the postulate of precision and the postulate of justification (Brożek 2017: 21; preprint).

I take this distance towards political, national and ideological matters to be a result of the school's anti-irrationalism. So, there was no position of the school itself towards Jews or any other ethnic or religious group, and no position towards any widely discussed social matter.

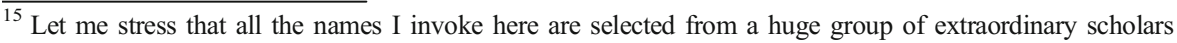
associated with LWS.
} 
However, members of LWS individually voiced out opinions in private and in public. Łukasiewcz, for example, was engaged in political life, serving as Minister of Religious Denominations and Public Education in 1919, and twice as rector of the University of Warsaw (1922-23 and 1931-32). Ajdukiewicz and Kotarbiński, following Twardowski in this respect, were also concerned with the issues of public education, and the social role of logic and philosophy.

I distinguish, therefore, between the content of a philosophical or logical theory, and the content of someone's ideological or political self-identification. Individual figures could have been biased, and although this had no impact on their theories proper, it could have had some impact on their collaboration, and thus - indirectly - on their results, too. Feferman \& Feferman (2004: 40-42) bring an interesting description of how the collaboration between Leśniewski and Tarski collapsed due to a specific combination of private and methodological reasons, mingled to the effect that the two broke their relationship for good, and Tarski would later on mention Kotarbiński as his true teacher.

So, one can debate on whether or not this or that member of LWS was true to the anti-irrational spirit of the school, especially under the ideological pressures from nationalism (Łukasiewicz, Leśniewski) or communism (Lindenbaum). This is a subject-matter that needs to be flagged, yet, unfortunately, there is no place here for a proper elaboration (for much more on the issue of LWS in relation to a broader political and ideological context of the interwar Poland, see Dunning 2018; an interesting overview can also be found in Tarski's biography by Feferman and Feferman 2004).

I believe that LWS and AIRR should be recognized against a broader background of the Polish intellectual and cultural legacy. And so is the case when it comes to the Polish-Jewish matters. I depict this background briefly in the subsequent sections.

\section{Anti-Irrationalism and the Polish Legacy}

\subsection{Some more General Remarks}

In this last part of the paper, after having characterized the main tenets of AIRR as well as its immediate environment, namely LWS, I would like to make some more general and speculative remarks, certainly drifting away from the core topic of this investigation, yet broadening the perspective for those interested in the Polish intellectual legacy at length.

Certainly someone might be surprised at this casting of AIRR as a more general label characterizing the Polish legacy. This is because LWS can be regarded as a late contribution to the Polish positivist movement, ${ }^{16}$ and the latter was a reaction to romanticism. Meanwhile, it is precisely romanticism, not positivism, which is frequently regarded as the best characterization of the Polish nation, and sometimes its bane (see

\footnotetext{
${ }^{16}$ Polish positivism emerged after 1864 among intellectuals reflecting on the disastrous ramifications of the January Uprising against Russia and considering different ways to regain Polish independence. The new approaches focused on laying a foundation for future independence through grass-roots level activities such as education, industrialization, etc., instead of causing more bloodshed. Let me be clear at this point: LWS comes about many years later and its relation to the initial reflection that spurred positivism in Polish lands is not immediate. The school nevertheless seems to carry on the positivist tradition at a time when many intellectuals and artists were beginning to experiment with yet another approach, a branch of European modernism called Young Poland (Polish: Młoda Polska). See e.g. Jadacki 2015; Skoczyńki and Woleński 2010.
} 
e.g. Janion 1975; Davies 2005). This is the dominant narrative both in Poland and abroad. I would like to at least show a prospect for a broader look at the issue.

Polish romanticism developed a messianic vision of the Polish nation according to which the Poles, whose state, once quite large and powerful, had been partitioned between Russia, Prussia and Austria in 1795, were like crucified Jesus, suffering - as Christianity teaches - for all the sins of mankind. In this view, like Jesus who freed humanity from original sin, the Polish nation offers freedom from oppression to peoples suffering under different forms of tyranny across the world (meaning, basically, in Europe in times of enlightened absolutism and later after the Congress of Vienna). ${ }^{17}$ As Adam Mickiewicz, one of the prominent members of the movement and one of the greatest poets of that period, put it, “(...) Poland said: 'Whoever will come to me shall be free and equal, for I am FREEDOM"“ (the quotation comes from Davies 2005: 7; see also Skoczyński and Woleński 2010; Jadacki 2015).

This messianic conception must seem radically obscure, but, in my opinion, we should recognize it against a broader context, as it is one among many other national mythologies such as being "the third Rome" or being "a City upon a Hill." All of them are attempts to tell a universal story about a particular group of people; a story that one group can tell other groups so that the latter can understand and sympathize with the former. ${ }^{18}$ Moreover, every such story posits a sort of "exceptionalism" as it attempts to unveil some supposedly unique features of the group in question. Surprisingly, this Polish "exceptionalism" even gained somewhat unintended praise from Franklin D. Roosevelt, who told Joseph Stalin at the Yalta Conference in 1945 that Poland "has been a source of trouble for over 500 years" (cited after Prizel 1998: 74). But why? Let us take FDR's words seriously for a moment. What made Poland "a source of trouble"?

\footnotetext{
${ }^{17}$ This myth took many forms, yet likely the most famous ones were delivered by Mickiewicz first of all in his poetic drama "Dziady" (English Forefathers' Eve), a great work of European romanticism, and in his "Ksiegi narodu polskiego i pielgrzymstwa polskiego" [English The Books of the Polish Nation From the Beginning of the World to the Martyrdom of the Polish Nation]. Here is a fragment from the latter, a gripping mythological story stylized in the form of an ancient prophecy:

"In the beginning, there was belief in one God, and there was Freedom in the world. And there were no laws, only the will of God, and there were no lords and slaves (...). Then the Kings, renouncing Christ, made new idols which they set up in the sight of the people, and bade them bow down (...) So the kings made an idol for the French and called it HONOUR; and this was the same that was called (...) the Golden Calf. And for the Spaniards, their king made an idol called POLITICAL POWER; and this was the same that the Assyrians worshipped as Baal (...). And for the English, their king made an idol called SEA POWER AND COMMERCE, which was the same as Mammon (...) And for the Germans, an idol was made called BROTSINN or Prosperity which was the same as Moloch (...). But the Polish nation alone did not bow down (...) And finally Poland said: 'Whoever will come to me shall be free and equal, for I am FREEDOM'. But the Kings when they heard were frightened in their hearts, and said (...) 'Come, let us slay this nation' (...)” (cited after Davies 2005: 7)

${ }^{18}$ This special status of the category of freedom in the self-image of the Poles goes back to the ideology prevailing in the seventeenth and eighteenth centuries, when the multicultural Polish-Lithuanian Commonwealth, reaching far to the East, yet built upon foundations of the Latin legacy and law, was regarded by its citizens as the Antemurale Christianitatis, the bulwark of Christendom, defending Western civilization primarily against the Turks. The view must have seemed appealing especially after the Battle of Vienna (1683) against the Ottoman Empire, won decisively by king John III Sobieski; see Butterwick (2001); Davies 2005. I would risk a claim that there seems to be no difference in principle between this Polish myth of freedom and, to take a much more contemporary example, "a calling from beyond the stars to stand for freedom", a duty to "extend the frontiers of freedom" which is "the everlasting dream of America." (From the speech of George W. Bush in 2004: See:

http://www.presidency.ucsb.edu/ws/index.php?pid=72727\& [accessed on JAN 312018])
} 
Disregarding the romantic exaggeration, hardly bearable for the contemporary (especially non-Polish) reader, it must have had to do with the way Poles had governed themselves (for an overview see Butterwick 2001; Davies 2005; Zamoyski 2012).

Keeping in mind that positivism, broadly construed, was a reaction to romanticism, we can consider romanticism a reaction, too. But to what? I would join those believing that it was a reaction to the spectacular collapse of the political project of the PolishLithuanian Commonwealth in the late eighteenth century (see Butterwick 1998, 2001; Davies 2005; Zamoyski 2012). In my view, this project was characterized by several genuinely anti-irrational postulates. Of course, I do not hold that we can actually speak of AIRR in the sixteenth and seventeenth centuries, but rather that we can see the abovementioned political project anew through the lens of AIRR as unpacked here. This merits a separate debate and a whole research project, but let me make some brief remarks on the prospect of such a reading.

First, some historical facts. The Polish-Lithuanian Commonwealth legally came into being in 1569, when the Union of Lublin was established, merging two states, ruled by one monarch already from the 1440s - the Kingdom of Poland and the Grand Duchy of Lithuania - into a single organism measuring about one million square kilometers, covering large parts of today's Poland, Lithuania, Latvia, Estonia, Belarus, Ukraine, and some fragments of today's Russia (the Kaliningrad District and the area around Smolensk). ${ }^{19}$ It was populated by a vast diversity of ethnic and religious groups, including Catholics, Orthodox Christians, Jews, Muslims, and later on, Protestants. Politically, the country was decidedly dominated by (someone might say in thrall to) the nobility, szlachta, to the disadvantage especially of peasants and people living in cities. However, the group of recognized nobles made up about $15 \%$ of the entire population, which made it the largest franchise in those days, especially when compared to the numbers of nobles in France or Germany, where they made up no more than $1 \%$ of the population (see Dewald 1996).

The Commonwealth was established by several institutions and founding documents. The most important ones included:

- The institution of free election. Starting from 1573, the Commonwealth was an elective monarchy with monarchs chosen by an assembly of nobles. ${ }^{20}$

- The Nihil Novi constitution from 1505, stipulating that the king is forbidden to issue laws and demand taxes without the consent of the parliament. This is the beginning of what would become known as the nobles' democracy (Polish: demokracja szlachecka).

- The Warsaw Confederation from 1573, granting religious freedom; the first act of this kind in Europe torn apart by religious wars at the time.

- The Henrician Articles from 1573, ${ }^{21}$ effectively functioning as the first Polish constitution up to 1791 . The Articles were a "contract" signed by all of Poland's

\footnotetext{
${ }^{19}$ In fact, these two states had been united before by personal union starting in the late fourteenth century, and from 1434 each subsequent king of Poland from the Jagiellonian dynasty (originally from Lithuania) was also a Grand Duke of Lithuania.

${ }^{20}$ The assembly might have accommodated from 10 to even 100,000 people, but most historians accept a modest number oscillating between 15 and 20 thousand. They met traditionally in the village of Wola near Warsaw (now part of the city).

${ }^{21}$ Named after the first elected king who signed them, Henri de Valois, who would later become Henry III of France.
} 
elected monarchs, stipulating that once they take power, they will accept all the previously guaranteed privileges of the citizens, including freedom of religion, freedom to resist royal power should the monarch break the law, etc., in addition to the structure of government.

This is basically the architecture of a republican system of governance, designed, in line with Aristotle, as a mix of monarchy, aristocracy, and democracy.

As a state, the Polish-Lithuanian Commonwealth was perceived differently than other big European states. This difference became apparent starting at least from the Peace of Westphalia (1648) which put an end to a series of religious conflicts sparked by the Reformation, which is widely regarded as the beginning of the emergence of the concept of the modern state. Since there were no serious religious conflicts, or at least no bloodshed in the Polish-Lithuanian territories (see Knoll 2011), ideas of what constituted a sovereign state in Western Europe and in the Commonwealth drifted apart. This would have dire ramifications as early as the seventeenth and especially in the eighteenth century, with the essentially decentralized Commonwealth becoming increasingly hostage to local and individual interest groups and the neighboring states becoming more centralized. The Polish contemporary thinker Jan Sowa (2011) claims suggestively that when compared with other European states of the same period, the Polish-Lithuanian Commonwealth was not a state proper, but a sort of a phantom. And once this "phantom" perished in 1795, Poland became an idea opposed to the political reality, as Norman Davies (Davies 2005) once described; a mere idea in people's heads, struggling to become reality for more than one hundred years (up to 1918); an idea garbed over the course of the nineteenth century in romantic clothes.

I would like to propose a different view. Poland or the Commonwealth (Poles liked to simply refer to it as Rzeczpospolita which means republic or rather the Republic, meaning their Polish-Lithuanian republic) was an idea from the very beginning, but it is not correct to oppose it to reality. Rather, it should be thought of as a project, a regulatory idea, sometimes an ideal. Historically, this reading draws on the central role played by the concept of law in Polish political theory and practice starting from the fifteenth century. For example, Jan Ostroróg (1436-1501) claimed that it is precisely the law that establishes a state, and put stress upon the independence of state law from the Church. ${ }^{22}$ The most groundbreaking figure of that period, Andrzej Frycz Modrzewski (Latin Andreas Fricius Modrevius, 1503-1572) argued, among many other things, that everyone is equal under the law, whether a peasant, noble or even the king (see Ulam 1946; Skoczyński and Woleński 2010; Louthan 2011; Huber 2014; Ptaszyński 2015; also in some respects Butterwick 2001).

Hence, the founding role with regard to the state was played not by extramundane factors (like God's will), a mythologized political power (as in the era of so-called enlightened absolutism), or by ethnicity or even language, but by a product of human thought - the law. This is the sense in which I would call Rzeczpospolita an idea or project.

One might say, and not without justification, that the Polish-Lithuanian Commonwealth fell short of standing up to the ideal of a law-governed society in which everyone is equal under the law, especially due to the actual enslavement of the

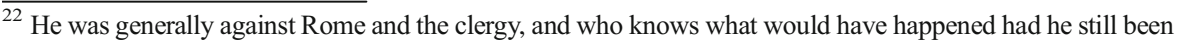
alive when Martin Luther spoke out.
} 
peasants (see e.g. Sowa 2011), yet there are always two measures that have to be taken into account in such contexts: how many people suffered from the failure to stand up to the ideal, and how many people nonetheless benefited from the actual achievements made. Compare it with the ideas of freedom, equality and law that lay at the foundation of the United States, and how much had to be done in the struggle to actually enfranchise slaves, women, and the poor (and how much of that struggle is still ongoing). Yet, the said ideas still serve as a source of inspiration and fuel the struggle.

\subsection{The Polish Legacy Between AIRR and IRR}

The reason I am citing all of these historical facts is this: in my view, the political project laid down in the Polish-Lithuanian Commonwealth's republican system of government did satisfy the conditions of AIRR at some points.

We can speak here of the political world-perspective and examine its commitment either to AIRR or IRR. First of all, the very idea that the Rzeczpospolita is established by its laws, and that every institution, including the king and the Church, falls under the law, belongs to AIRR insofar as laws are the result of social practices and are not Godgiven. This was a departure from the myth anchoring political power in some extramundane realm. Power comes from social practices. Note one subtle point here: in this view, the very phenomenon of sociability is not a result of imposing power on otherwise asocial creatures; instead, social association results from human beings' implicit pursuit of rationality. We thus have a genuinely optimistic assessment of human nature: people can by themselves come to terms on things that matter to them.

However, together with political power itself, it is also impossible on the grounds of AIRR to invest any social structure, thus also any social hierarchy, with mythical grounding, and this implication created an interesting gulf in the Rzeczpospolita. On the one hand, Frycz Modrzewski called for equal rights for members of all social classes. Even more radically, the Polish Brethren Protestant movement was very outspoken in the mid-sixteenth century (sic!) on the idea of a society without class divisions (its members were also called Socinians which celebrates the name of the Italian reformist Faustus Socinus who spent about 25 years of his adult life in Poland and influenced the movement).

Thus, demythologization of political power and of the social order resulted in an awareness of the actual political world-perspective, including the actual social hierarchy being $a$ political perspective, meaning that citizens were aware of there being other options. No political world-perspective, conditioned by social practices can therefore be regarded as bonded to an alleged unconditioned reality. And this constitutes one of the hallmarks of AIRR.

On the other hand, however, the Polish nobility, on account of its size and the political power it wielded, was relentless in protecting its group interests against the interests of other groups, which eventually led to an obscure mythologization of its own origins (the ideology of sarmatism). Hence the paradox: initially driven by AIRR, namely to demythologize political power, the nobles later succumbed to IRR, with the mythologization of the nobility itself.

Further on, freedom of religion, as guaranteed by the Warsaw Confederation and the Henrician Articles, is also a manifestation of AIRR and goes hand in hand with the demythologization of political power. King Sigismund II Augustus (Polish: Zygmunt II 
August) famously said: "I am not the king of your consciences" (cited after Knoll 2011: 34 ), and this declaration implicitly opposed the golden rule of religious peace in Western Europe, namely cuius regio eius religio, endowing political power with the capacity to make religious choices in the name of the people. Along with the demythologization of political power within a political world-perspective, the perspective itself was demythologized in yet another way: if there are different ways of setting up one's relationship with God, there is no reason to grant any political world-perspective a special status based on the assumption that it offers the right way of setting up the said relationship. And what goes for religion, goes for all other kinds of worship, too, including the worship of Reason or History, or of any other allegedly unconditioned order. The general message is clear: there is no political world-perspective that offers us an intimate bond with the divine or otherwise unconditioned realm, and this is truly a refreshing call whenever a political ideology looms on the horizon.

The issue of religious tolerance in the Polish-Lithuanian Commonwealth also refers to Jews who regarded the Rzeczpospolita, at least at some point, as Paradisus Judaeorum (see Hundert 1997). Of course, it is not supposed to say that there were no acts of hostility toward Jews; rather - that there was not hostility built-into-the-structure of the state itself (see Hundert 1981; Polonsky 2010, 2013). The historian T. Snyder makes interesting notes about it in his review of Polonsky (2010) in The Wall Street Journal:

Under the commonwealth, Jews experienced what Mr. Polonsky calls a "sense of security." The political system of the commonwealth was a kind of aristocratic republic, in which nobles formed the legislature and elected their king. This marginalized the two estates that had the most obvious interest in discriminating against Jews: the Christian burghers of the cities and the Roman Catholic Church. (Snyder 2012)

However, in his book Polonsky (2010) also points out that the transformation that gave rise to modernity in the West consisted of centralization of the states which established a direct relationship between political authorities on the one hand and individual citizens on the other, thereby emancipating the latter from their traditional communities. Meanwhile, this was not the case in the Rzeczpospolita as the state weakened in the eighteenth century together with all the institutions that could secure the rights of minorities undergoing the said process of transformation. The latter posed even bigger challenges to the Jewish communities, according to Polonsky. The perpetuating crisis and finally the collapse of the Polish-Lithuanian Commonwealth in the eighteenth century left the minorities vulnerable. In effect, in the nineteenth century, Poles have no institutions and no real interest in protecting Jews, focusing their attention of finding means to regain freedom, meanwhile under Russian rule, according to Polonsky, Jews started to be blamed by the czars for the failures of their own policies, which resulted in anti-Semitic resentments and pogroms. All this is not supposed to peddle a simplified story of perfectly harmonious coexistence of cultures in the Rzeczpospolita; reality is always more complex. Yet, it seems clear to some scholars that the collapse of the Polish-Lithuanian Commonwealth had disastrous consequences for the Poles as well as for the Polish Jews (see Hundert 2004; Polonsky 2013; for a broader perspective also Woleński 2011; some notes on the issue can also be found in Tarski's biography by Feferman and Feferman 2004). 
This way I go back to my main speculation in order to unveil a peculiar dialectics of IRR and AIRR. Namely, surprisingly indeed, when political power is granted with religious or religious-like authority, e.g. succumbing to IRR and portraying itself as the only dispenser of Truth, Reason and Enlightenment, it can at times also have positive ramifications. Namely, political power granted with the mentioned authority can also prevent IRR, if those in power wish to do so. Meanwhile, when there is no link between people's natural pursuit of "the unconditioned", as Kołakowski puts it, and political power, and moreover when the state is decentralized, this may result in a proliferation of IRR simply because there is no agent able to stem the tide of IRR. So, paradoxically again, AIRR at one point, namely the demythologization of political power, paves the way for IRR at some other point.

Finally, there is also a risk of getting caught up in a bubble-like political world perspective. Once a group constructing a shared political world-perspective neglects channels of communication with those outside the group, it may become unable to defend the group's interests, whether in dialogue or in confrontation with other groups. Secondly, there is the risk of being unable to apprehend important information from outside. In short: if others cannot understand you, it is also likely that you are unable to understand them.

In this context, the conclusion we can draw from the quoted statement by FDR is this: Poland developed a model of governance that represented a complete departure from the ways followed by other big countries in Europe. This is not wrong by itself, contrary to what many Poles would claim later (e.g., the Cracow school of historians from late nineteenth century). However, it is definitely wrong that Poland failed to make its way of living and governing communicable (and, in some sense, testable) to other nations, thereby weakening its own ability to adjust to trends that would prove beneficial and long lasting, e.g., urbanization and industrialization (see Sowa 2011; and Cichocki 2018 for an entirely different perspective).

This was not the case from the beginning, if one takes into account that in the sixteenth century, the Rzeczpospolita became a safe haven for many outliers from around Europe, who must have found its somewhat peculiar government organization attractive. And several writers, including Frycz Modrzewski (see Ulam 1946; Huber 2014; Ptaszyński 2015) and members of the Polish Brethren, had, in turn, a notable influence on the development of religious (therefore political, too) thought in Europe, especially on Newton and Locke (see e.g. McLachlan 1941; Snobelen 1999; Dixon 2003; Hewett 2004; Muslow and Rohls 2005; more recently, Wagner and Briggs 2016 also make a note about it; see Chapter 32 on Newton). The Polish Brethren created in 1602 the Racovian Academy in a small town named Raków, near Kielce in Poland, which was the main center of their thought and publishing activity (see Hewett 2004). ${ }^{23}$ Already in exile, in Amsterdam, they published in 1668 a series of books under the name Bibliotheca Fratrum Polonorum quos Unitarios vocant (Library of the Polish Brethren called Unitarians). In a footnote added to the collection of papers by John Locke (2012) by V. Nuovo we read:

\footnotetext{
${ }^{23}$ For the original papers in Latin see the archive here:

https://www.sbc.org.pl/dlibra/publication/7381/edition/6882
} 
Locke's personal library included numerous 'Racovian' works, many acquired by him during his exile in the Netherlands (1683-9), among them is Bibliotheca Fratrum Polonorum (...) (Locke 2012: 18)

Dixon makes an interesting note, too:

In 1605 the collage of Racow had produced a catechism in Polish, known ever after as 'the Racovian Catechism' which aimed to be a compendium of Socinian teaching. (...) The catechism was soon translated into Latin, and in 1609 it arrived in England complete with a dedication to James I, whom the Socinians mistakenly believed to be a model of religious toleration. James was appalled and the book was burnt by the hangman." (Dixon 2003: 40)

Nevertheless, there was surely a point at which the said organization of government got pathologized, religious tolerance ended (see Tazbir 1970 for a broader picture), these channels of communication became closed and never opened again, to the effect that in his correspondence with Empress Catherine II of Russia (see Reddaway 1931) Voltaire expressed the belief that partitioning Poland was an act of justice. He did so, believing that he and Catherine (sic!) carried the lamp of Reason in the era of Enlightenment, while the Poles were incurably irrational. So at the end of the day Poland's failure to stand up to the conditions of AIRR, including the one referring to what I have called cross-perspective communication, ended up weakening its ability to defend itself against potentially dangerous factors such as the centralization of power in neighboring countries. And weakening its ability to learn from others. A sad memento, but also a call to self-awareness to political projects based on the praise of reason without the worship of Reason.

Acknowledgements I would like to thank Asa Kasher for the invitation to write this paper and Joanna Niżyńska for making it possible for me to present a part of this work at the Polish Studies Center, Indiana University Bloomington. My visit to Bloomington also would not have been possible without the support of Colin Allen. Last but not least, many thanks to the reviewers of this paper, whose remarks contributed to making the final version much better than the first one. Completing this work was supported by the grant UMO2016/20/S/HS1/00046 provided by the National Science Centre, Poland.

Open Access This article is distributed under the terms of the Creative Commons Attribution 4.0 International License (http://creativecommons.org/licenses/by/4.0/), which permits unrestricted use, distribution, and reproduction in any medium, provided you give appropriate credit to the original author(s) and the source, provide a link to the Creative Commons license, and indicate if changes were made.

\section{References}

Ajdukiewicz, K. (1931). O znaczeniu wyrażeń (On the Meaning of Expressions), Ksiega Pamiątkowa Polskiego Towarzystwa Filozoficznego we Lwowie, Lwów, 31-77. English version in Ajdukiewicz (1978).

Ajdukiewicz, K. (1934). Sprache und Sinn [Language and meaning]. Erkenntnis, IV, 100-138. English version in Ajdukiewicz (1978).

Ajdukiewicz, K. (1934a). Das Weltbild und die Begriffsapparatur. Erkenntnis, IV, 259-287. English version in Ajdukiewicz (1978).

Ajdukiewicz, K. (1935). Der logistische Antiirrationalismus in Polen. Erkenntnis, V, 151-164. 
Ajdukiewicz, K. (1937). Problemat transcendentalnego idealizmu w sformufowaniu semantycznym [A semantical version of the problem of transcendental idealism]. Przeglad Filozoficzny, XL, 271-287. English version in Ajdukiewicz (1978).

Ajdukiewicz, K. (1949). The scientific world-perspective. In H. Feigl \& W. Sellars (Eds.), Readings in philosophical analysis (pp. 182-190). New York: Appleton-Century-Crofts. Original version in Ajdukiewicz (1935a).

Ajdukiewicz, K. (1950). Logic and experience. Synthese VIII (6-7): 289-299. Reprinted in Ajdukiewicz (1978).

Ajdukiewicz, K. (1963). Zagadnienie uzasadnienia [The problem of foundation]. Studia Filozoficzne, 2, 4-13.

Ajdukiewicz, K. (1964). Zagadnienie empiryzmu a koncepcja znaczenia [The problem of empiricism and the concept of meaning]. Studia Filozoficzne, 1, 3-14. English translation in Ajdukiewicz (1978).

Ajdukiewicz, K. (1975). Problems and theories of philosophy. Cambridge: Cambridge University Press.

Ajdukiewicz, K. (1978). The scientific world-perspective and other essays, 1931-1963. Dordrecht-Boston: D. Reidel.

Betti, A. (2017). Kazimierz Twardowski. In. E. Zalta (Ed.) The Stanford Encyclopedia of Philosophy (Fall 2017 Edition), URL = https://plato.stanford.edu/archives/fall2017/entries/twardowski/ . Accessed 04 Apr 2019.

Beziau, J.-Y. (2018). The Lvov-Warsaw school: A true mythology. In Garrido \& Wybraniec-Skardowska, 2018, 779-815.

Brożek, A. (2011). Kazimierz Twardowski. Der Wiener Jahre. Wien-New York: Springer.

Brożek, A. (2017). Maria Kokoszyńska: Between the Lvov-Warsaw school and the Vienna circle. Journal for the History of Analytic Philosophy, 5(2). https://doi.org/10.15173/jhap.v5i2.2927.

Brożek, A., Stadler, F., Woleński, J. (Eds) (2017). The Significance of the Lvov-Warsaw School in the European Culture (Vienna Circle Institute Yearbook Vol. 21): Dordrecht: Springer.

Butterwick, R. (1998). Poland's last king and English culture: Stanistaw august Poniatowski, 1732-1798. Oxford: Oxford University Press.

Butterwick, R. (Ed.). (2001). The polish-Lithuanian monarchy in European context, c. 1500-1795. Basingstoke: Palgrave.

Carnap, R. (1934). Logische Syntax der Sprache, Wien: Springer. English translation: The logical syntax of language. London: Kegan Paul 1937.

Chrudzimski, A. (2016). Kazimierz Ajdukiewicz on transcendental idealism from a semantic point of view. Studies in East European Thought, 68(1), 63-74.

Cichocki, M. (2018). Północ i Poludnie. Teksty o polskiej kulturze i historii. Warszawa: Teologia Polityczna.

Cignoli, R. (2007). The algebras of Łukasiewicz many-valued logic: A historical overview. In S. Aguzzoli, A. Ciabattoni, B. Gerla, C. Manara, \& V. Marra (Eds.), Algebraic and proof-theoretic aspects of nonclassical logics. Berlin-Heidelberg: Springer.

Cohen, R. S., \& Schnelle, T. (Eds.). (1986). Cognition and fact. Materials on Ludwik Fleck. Dordrecht: Springer.

Davies, N. (2005). God's Playground. A History of Poland. Vol. II: 1795 To the present (revised edition]. Oxford: Oxford University Press.

Dewald, J. (1996). The European nobility, 1400-1800. Cambridge: Cambridge University Press.

Dixon, P. (2003). Nice and hot disputes. In The doctrine of the trinity in the seventieth century. London-New York: T \& T Clark.

Dunning, D. E. (2018). The logic of the nation: Nationalism, formal logic, and interwar Poland. Studia Historiae Scientiarum, 17, 207-251. https://doi.org/10.4467/2543702XSHS.18.009.9329.

Feferman, A., \& Feferman, S. (2004). Alfred Tarski: Life and logic. Cambridge: Cambridge University Press.

Flaxman, S., Goel, S., \& Rao, J. M. (2016). Filter bubbles, Echo chambers, and online news consumption. Public Opinion Quarterly, 80, 298-320.

Fleck, L. (1935). Entstehung und Entwicklung einer wissenschaftlichen Tatsache. Einführung in die Lehre vom Denkstil und Denkkollektiv. Basel: Benno Schwabe. English translation: Genesis and Development of a Scientific Fact. Chicago: Chicago University Press 1979.

Garrido, Á., \& Wybraniec-Skardowska, U. (Eds.). (2018). The Lvov-Warsaw school. Past and present. Basel: Birkhäuser.

Gettier, E. (1963). Is justified true belief knowledge? Analysis, 23, 121-123.

Gigerenzer, G. (2008). Rationality for mortals: How people cope with uncertainty. New York: Oxford Univ. Press.

Grobler, A. (2013). Renowacja radykalnego konwencjonalizmu. Przeglad Filozoficzny, 4(88), 183-196.

Hayek, F. A. (1980). Counter revolution of science. Studies on the abuse of reason. Indianapolis: Liberty Fund Inc..

Hewett, P. (2004). Racovia: An early Liberal religious community. Providence: Blackstone Editions.

Huber, S. (2014). Polifonia tradycji. Filozofia praktyczna i teoretyczna Andrzeja Frycza Modrzewskiego. Warszawa: Uniwersytet Warszawski \& Wyd. Sub Lupa. 
Hundert, G. (1981). An advantage to peculiarity? The case of the polish commonwealth. AJS Review, 6, 21-38. Hundert, G. (1997). Poland: Paradisus Judaeorum. Journal of Jewish Studies, 48(2), 335-348.

Hundert, G. (2004). Jews in Poland-Lithuania in the eighteenth century. A genealogy of modernity. BerkeleyLos Angeles: University of California Press.

Ingarden, R. (1964) Der Streit um die Existenz der Welt, Bd. I, II/I, II/2. Tübingen: Max Niemeyer. English translation of volume 1: R. Ingarden, controversy over the existence of the world Vol. I. Frankfurt: Peter Lang 2013.

Ingarden, R. (1979). The literary work of art: An investigation of the borderlines of ontology, logic, and theory of language. Evanston: Northwestern University Press.

Jadacki, J. (2009). Polish analytical philosophy. Studies on its heritage. Warsaw: Semper.

Jadacki, J. (2015). Polish philosophy of the 19th and 20th centuries. Semper: Heritage Studies. Warsaw.

Janion, M. (1975). Goraczka romantyczna. Warszawa: PIW.

Jedynak, A. (2003). Ajdukiewicz. Warszawa: Wiedza Powszechna.

Jedynak, A. (2013). Ajdukiewicz: granice racjonalizmu. Przeglad Filozoficzny, 4(88), 365-380.

Knoll, P. W. (2011). Religious toleration in sixtieth-century Poland: Political realities and social constraints. In H. Louthan, G. B. Cohen, \& F. A. J. Szabo (Eds.), Diversity and dissent. Negotiating religious difference in Central Europe: 1500-1800 (pp. 30-53). New York: Berghahn Books.

Kołakowski, L. (1989). The presence of myth. Chicago: The University of Chicago Press.

Kołakowski, L. (2008). Main currents of Marxism: The founders - the Golden age - the breakdown. New York - London: W. W. Norton \& Company.

Kolodny, N. (2005). Why be rational? Mind, 114(455), 509-563.

Kotarbiński, T. (1968). Reism: Issues and prospects. Logique et Analyse, 11, 441-458.

Kuhn, T. (1962). The structure of scientific revolutions. Chicago: Chicago University Press.

Küng, G. (1988). Ajdukiewicz's contribution to the realism/idealism debate. In K. Szaniawski (Ed.), The Vienna circle and the Lvov-Warsaw school (Nijhoff international philosophy series) (Vol. 38, pp. 67-85). Dordrecht: Springer.

Lapointe, S., Wolénski, J., Marion, M., \& Miskiewicz, W. (Eds.). (2009). The Golden age of polish philosophy. Kazimierz. Twardowski's philosophical legacy. Dordrecht: Springer.

Latour, B. (2005). Reassembling the social : An introduction to actor-network theory. Oxford: Oxford University Press.

Leśniewski, S. (1992). Collected works - volumes I and II, Edited by Surma, S.J., Srzednicki, J.J.T., Barnett, D.I., Rickey, V.F., Dordrecht: Springer.

Linsky, B. (2009). Leon Chwistek's theory of constructive types. In. Lapointe, S., Wolénski, J., Marion, M., Miskiewicz, W. (Eds.) (2009): 203-219.

Locke, J. (2012). Vindications of the reasonableness of Christianity. Edited with Introductions, Notes and Critical Apparatus by V. Nuovo. Oxford: Oxford University Press.

Louthan, H. (2011). Multiconfessionalism in Central Europe. In T. M. Safley (Ed.), A companion to Multiconfessionalism in the early modern world (pp. 369-392). Leiden: Brill.

Łukasiewicz, J. (1970). Selected works. Amsterdam-London: North-Holland.

Matz, S. C., Kosinski, M., Nave, G., \& Stillwell, D. J. (2017). Psychological targeting as an effective approach to digital mass perssuasion. PNAS, 114(48), 12714-12719. https://doi.org/10.1073/pnas.1710966114.

McLachlan, H. (1941). The religious opinions of Milton, Locke and Newton. Manchester: Manchester University Press.

Murawski R. (2014). Lvov-Warsaw School of Philosophy. In: The philosophy of mathematics and logic in the 1920 s and 1930s in Poland. Science Networks. Historical studies, vol 48. Birkhäuser, Basel.

Muslow, M., \& Rohls, J. (Eds.). (2005). Socinianism and Arminianism. Antitrinitarians, Calvinists and cultural exchange in seventeenth-century Europe. Leiden-Boston: Brill.

Niiniluoto, I. (2002). Kotarbiński as a scientific realist. Erkenntnis, 56(1), 63-82.

Pariser, E. (2011). The filter bubble: What the internet is hiding from you. London: Penguin.

Peacocke, C. (2003). The realm of reason. Oxford: Oxford University Press.

Perzanowski, J. (2012). Art of philosophy. A selection of Jerzy Perzanowski's works. Frankfurt: Ontos Verlag.

Polonsky, A. (2010). The Jews in Poland and Russia. Vol I, 1350 to 1881. Oxford: Littman Library of Jewish Civilization.

Polonsky, A. (2013). The Jews in Poland and Russia: A short history. Liverpool: Liverpool University Press.

Prizel, I. (1998). National Identity and foreign policy. Nationalism and leadership in Poland, Russsia, and Ukraine. Cambridge: Cambridge University Press.

Ptaszyński, M. (2015). The polish-Lithuanian commonwealth. In H. Louthan \& G. Murdock (Eds.), A Companiion to the reformation in Central Europe (pp. 40-67). Leiden-Boston: Brill.

Reddaway, W. F. (1931). Documents of Catherine the great: The correspondence with Voltaire and the instruction of 1767 in the English text of 1768. Cambridge: Cambridge University Press. 
Rojszczak, A. (2005). From the act of judging to the sentence: The problem of truth bearers from Bolzano to Tarski: 328 (Synthese library). Dordrecht: Springer.

Sady, W. (2017). Ludwik Fleck. In. E. Zalta (Ed.) The Stanford Encyclopedia of Philosophy (Fall 2017 edition), URL = https://plato.stanford.edu/archives/fall2017/entries/fleck/. Accessed 2 Nov 2018.

Schafer, K. (forthcoming). Rationality as the capacity for understanding. Noûs. Manuscript available on https://webfiles.uci.edu/schaferk/www/RationalityUnderstanding-Nous-Final.pdf. Accessed 04 Apr 2019.

Searle, J. R. (2001). Rationality in action. Cambridge: MIT Press.

Simons, P. (1987). Parts. A study in ontology. Oxford: Clarendon Press.

Sinisi, V., \& Woleński, J. (Eds.). (1995). The heritage of Kazimierz Ajdukiewicz. Amsterdam: Rodopi.

Skoczyński, J., \& Woleński, J. (2010). Historia filozofii polskiej. Kraków: WAM.

Skolimowski, H. (1967). Polish analytical philosophy. London: Routledge and Kegan Paul.

Skolimowski, H. (1995). The participatory mind : A new theory of knowledge and of the universe. London: Penguin Books.

Smith, B. (1989). Kasimir Twardowski: An essay on the borderlines of ontology, psychology and logic. In K. Szaniawski (Ed.), The Vienna circle and the Lvov-Warsaw school (Nijhoff international philosophy series) (Vol. 38, pp. 313-373). Dordrecht: Springer.

Snobelen, S. D. (1999). Isaac Newton, heretic: The strategies of a Nicodemite. British Journal for the History of Science, 32, 381-419.

Snyder, T. (2012). Their sense of belonging. The Wall Street Journal May 18th 2012; available on-line: https://www.wsj.com/articles/SB10001424052702304192704577404002010111404. Accessed 04 Apr 2019.

Sowa, J. (2011). Fantomowe ciało króla. Peryferyjne zmagania z nowoczesna forma. Kraków: Universitas.

Surma, S. J. (1973). Mordechaj Wajsberg. Live and works. Bulletin of the Section of Logic, 2(2), 91-96.

Tarski, A. (1944). The semantic conception of truth and the foundations of semantics. Philosophy and Phenomenological Research, 4(3), 341-376.

Tarski, A. (1983). Logic, semantics, Metamathematics: Papers from 1923 to 1938. Indianapolis: Hackett Publishing.

Tazbir J. (1970). Sarmatyzacja katolicyzmu w XVII wieku. In. J. Pelc (Ed.) Wiek XVII - Kontrreformacja Barok. Wrocław-Warszawa-Kraków: Ossolineum: 7-37.

Thi Nguyen C. (2018). Cognitive islands and runaway echo chambers: Problems for epistemic dependence on experts. Synthese. On-line first, https://doi.org/10.1007/s11229-018-1692-0.

Thomasson, A. (2017). Roman Ingarden. In. E. Zalta (Ed.) The Stanford Encyclopedia of Philosophy (Fall 2017 Edition) URL = https://plato.stanford.edu/archives/fall2017/entries/ingarden/ . Accessed 04 Apr 2019.

Tischner J. (1984). The Spirit of solidarity (English and Polish edition), Harper \& Row.

Tversky, A., \& Kahneman, D. (1974). Judgment under uncertainty: Heuristics and biases. Science, 185, 1124-1130.

Twardowski, K. (1999). On actions, products and other topics in philosophy. Amsterdam: Rodopi.

Ulam, A. (1946). Andreas Fricius Modrevius-a polish political theorist of the sixteenth century. The American Political Science Review, 40(3), 485-494.

van der Schaar, M. (2015). Kazimierz Twardowski: A Grammar for Philosophy. Leiden: Brill.

Wagner, R., \& Briggs, A. (2016). The penultimate curiosity. How science swims in the slipstream of the ultimate questions. Oxford: Oxford University Press.

Wansing, H. (2002). Praface. Erkenntnis, 56(1), 5-8.

Witkiewicz, S. I. (1969). Madman and the Nun and other plays. Seattle: University of Washington Press.

Witkiewicz, S. I. (1992). The Witkiewicz Reader. Evanston: Northwestern University Press.

Woleński, J. (1989a). The Lvov-Warsaw school and the Vienna circle. In K. Szaniawski (Ed.), The Vienna circle and the Lvov-Warsaw school (Nijhoff international philosophy series) (Vol. 38, pp. 443-453). Dordrecht: Springer.

Woleński, J. (1989b). Logic and philosophy in the Lvov-Warsaw school (Synthese library). Dordrecht: Kluwer.

Woleński, J. (1990). Kotarbiński. Warszawa: Wiedza Powszechna.

Woleński, J. (1995). Mathematical logic in Poland 1900-1939: people, circles, institutions, ideas. Modern Logic, 5(4), 363-405.

Woleński, J. (2002). From intentionality to formal semantics (from Twardowski to Tarski). Erkenntnis, 56(1), 9-27.

Woleński, J. (2011). Szkice o kwestiach żydowskich. Kraków: Austeria.

Woleński, J. (2017). Lvov-Warsaw School, in. E. Zalta (Ed.) The Stanford Encyclopedia of Philosophy (Fall 2017 Edition) URL = https://plato.stanford.edu/archives/fall2017/entries/lvov-warsaw/ . Accessed 04 Apr 2019. 
Woleński, J., \& Simons, P. (1989). De Veritate: Austro-polish contributions to the theory of truth from Brentano to Tarski. In K. Szaniawski (Ed.), The Vienna circle and the Lvov-Warsaw school (Nijhoff international philosophy series) (Vol. 38, pp. 391-442). Dordrecht: Springer.

Zamoyski, A. (2012). Poland: A history. New York: Hippocrene Books.

Zaręba, M. (2017). On Kotarbiński's Praxiology and analytical philosophy of action. In. Brożek, et al. (2017), pp. $155-171$.

Zygmunt, J. (1991). Mojżesz Presburger: Life and work. History and Philosophy of Logic, 12(2), 211-223.

Zygmunt, J., \& Purdy, R. (2014). Adolf Lindenbaum: Notes on his life, with bibliography and selected references. Logica Universalis, 8(3-4), 285-320.

Publisher's Note Springer Nature remains neutral with regard to jurisdictional claims in published maps and institutional affiliations. 